\section{Dr. T. A. Munro}

Thomas Arthur Munro died on December 18, 1966, at the age of 61 . He had been medical superintendent of the Royal Edinburgh Hospital since 1954. At that time many developments were taking place, and Munro delighted in them, for he was a shrewd and practical man who made constant improvements in the general amenities of the hospital. His post was a demanding one, but he found time for clinical as well as administrative work.

Munro was educated at Edinburgh Academy and the University of Edinburgh, where he graduated M.B., Ch.B. in 1928. He was a resident in the Edinburgh Royal Infirmary and then joined the staff of Sir David Henderson in the Royal Edinburgh Hospital, Morningside. He was awarded a Beit fellowship and went to work with Professor Meyer in Baltimore and with Professor Macfie Campbell in Cambridge, Massachusetts. He returned to England and to a research post with Dr. Turner at the Royal Eastern Counties Institution and here his ability for research was revealed. Working with a large body of clinical material he investigated genetic and biochemical factors in the aetiology of what, for simplicity, can be called mental defect. Finally he was able to clarify the condition of oligophrenic phenylketonuria and its avoidability. This hopeful approach has continued to develop.

When the Second World War began he joined the Emergency Medical Service and later the R.A.M.C., where he became a colonel A.M.S. At the end of the war he was offered the position of chief of the Psychiatric Services in Guy's Hospital. This post was an arduous one; there was much administrative, teaching and clinical work; he had the interesting but difficult task of integrating the work of the Psychiatric Department with that of the hospital generally. A certain amount of private clinical work was inescapable, but he approached it all with enthusiasm until in 1954 he returned to be chicf of the hospital in which his career had begun. In 1965 he saw a new department, the Andrew Duncan Clinic, opened.

Munro was a man with a strong sense of humour and he was a good public speaker. He was still, in the sixties, being visited by American friends he had first met thirty years earlier. He was extremely social and it is a happy recollection that one of the last gatherings he organized was to celebrate the eightieth birthday of Sir David Henderson, from whom Munro gained much of the knowledge and experience which he used to the benefit of psychiatry.

W. M. H.

\section{Professor G. P. Crowden}

Professor G. P. Crowden, emeritus professor of applied physiology of the University of London, died at Edgware on November 22, 1966.

He was born in 1894, and had a distinguished academic career at the University of London, graduating B.Sc. with first class honours in physiology in 1921, M.Sc. in 1926, M.R.C.S., L.R.C.P. in 1929, D.Sc. in 1937 and in the same year he was elected M.R.C.P., London. He was appointed lecturer in physiology at University College in 1927 and at the London School of Hygiene in 1929, where he served successively as reader in industrial physiology and professor of applied physiology until his retirement in 1962. He was awarded the O.B.E. in 1944.

Crowden served with the British Expeditionary Force from 1915 to 1918 , first as intelligence officer and later for special duties with a gas brigade. He maintained his connexion with the armed forces through the Territorial Army and the O.T.C. medical unit, and served during the Second World War as colonel, R.A.M.C., in London and West Africa. Since then he has been consultant in applied physiology to the army and a member of the Army Personnel Research Committee.

In 1927 Crowden had spent a year at Harvard School of Public Health and early in his career he saw the need to apply the principles of engineering, physics and chemistry to the solution of problems of preventive medicine. His teaching and research covered an astonishingly wide range of subjects within the field of applied physiology and occupational health. He was a practising ergonomist many years before this word had been coined. Man's physiological environment and the reactions of man as a whole rather than of individual organs were his interests. Although his main research was in the field of muscular work, nutrition, noise and deafness, his interests ranged from comfort in living quarters in ships in tropical heat to insulation against cold in Antarctica. He published work on physiological problems of housing, protective clothing, artificial respiration and pneumatic drills. $\mathrm{He}$ did much to popularize the use of aluminium foil for reflecting radiant heat in solar topees and other headgear, fire-fighting suits and insulation of buildings.

He was a lucid and effective teacher, concentrating on the principles of the common ground between the relevant disciplines. Whether he was lecturing to the main classes of medical graduates or nurses or students of tropical architecture he emphasized the need to look for and, as far as possible, rectify any departure from optimum conditions of man at work or in the home. He was a strong advocate of the value of practical work, striving wherever possible to provide individual student participation; for example, every student had an opportunity to measure his own hearing by gramophone audiometer and to assess the components of the thermal environment, summarizing their overall effect on man by the effective temperature scale. There were many demonstrations in the evaluation of lighting, noise, radiant heat, muscular work, ventilation and protective clothing.

I shall long remember the applause from members of the Physiological Society after a communication given by Crowden at a meeting at the National Hospital, Queen Square. The subject was the superiority of nylon as compared with cotton mosquito nets with respect to permeability to air movement and to light. The spontaneous ovation showed that the audience as a whole appreciated the clear exposition of an important practical point, but it also owed much to their esteem and affection for the speaker.

M. L. THomson

\section{A. J. Berry}

Arthur John Berry, senior fellow emeritus of Downing College, Cambridge, and formerly university lecturer in chemistry, died on January 15, at the age of 81 .

He graduated from the University of Glasgow and then went to Cambridge, where he took his Natural Sciences Tripos. He started to teach chemistry in 1911, and this remained one of his great interests; he became director of studies in chemistry and physics at Downing College soon after his election as fellow in 1913, and continued in this post until his retirement in 1951. For many years Berry had great influence on the teaching of chemistry in Cambridge. His early research interests were in analytical chemistry; he was the author of several books on the subject and on the chemistry of the atmosphere. In his later years he was increasingly concerned with the history of science. Berry wrote a number of useful books on the history of chemistry, including a biography of Cavendish, which was notable for a particularly clear style and the obvious affection of the author for his subject. Although Berry made no original contribution his books will continue to be valuable as introductions for students for a long time.

Berry had served as vice-master of his college and as a senior proctor. 